\title{
Retrospective analysis of relationships among the dose regimen, trough concentration, efficacy, and safety of teicoplanin in Chinese patients with moderate-severe Gram-positive infections [Corrigendum]
}

\author{
Zhou L, GaoY, Cao W, et al. Infect Drug Resist. 2018;11:29-36.
}

On page 29, the first and second affiliations were listed incorrectly. The correct presentation of affiliations 1 and 2 should be as follows:

'Translational Medicine Center, Zhengzhou Central Hospital Affiliated to Zhengzhou University, Zhengzhou, China; ${ }^{2}$ Department of Respiratory Medicine, Zhengzhou Central Hospital Affiliated to Zhengzhou University, Zhengzhou, China

On page 29, the second correspondence author's name should read from Long Chen to Long Cheng.

\section{Publish your work in this journal}

Infection and Drug Resistance is an international, peer-reviewed openaccess journal that focuses on the optimal treatment of infection (bacterial, fungal and viral) and the development and institution of preventive strategies to minimize the development and spread of resistance. The journal is specifically concerned with the epidemiology of antibiotic

\section{Dovepress}

resistance and the mechanisms of resistance development and diffusion in both hospitals and the community. The manuscript management system is completely online and includes a very quick and fair peerreview system, which is all easy to use. Visit http://www.dovepress.com/ testimonials.php to read real quotes from published authors. 